\title{
Effect of subacute oral doses of nivalenol on immune and metabolic defence systems in mice
}

\author{
Marie-Estelle GouZE ${ }^{\mathrm{a}}$, Joëlle LAFFITTE ${ }^{\mathrm{a}}$, Philippe PINTON ${ }^{\mathrm{a}}$, \\ Geneviève DEDIEUX $^{\mathrm{b}}$, Anne GALINIER ${ }^{\mathrm{b}}$, Jean-Paul THOUVENOT ${ }^{\mathrm{b}}$, \\ Nicolas LOISEAU $^{\mathrm{a}}$, Isabelle P. OSWALD ${ }^{\mathrm{a}}$, Pierre GALTIER ${ }^{\mathrm{a} *}$ \\ a Laboratoire de Pharmacologie-Toxicologie, UR66, INRA, 180 Chemin de Tournefeuille, \\ 31931 Toulouse, France \\ b Laboratoire de Biochimie Générale et Nutritionnelle, CHU Purpan, Place du Dr Baylac, \\ 31059 Toulouse, France
}

(Received 21 December 2006; accepted 13 March 2007)

\begin{abstract}
Nivalenol (NIV) is a toxic Fusarium secondary trichothecene metabolite occurring naturally in cereal grains. In order to evaluate the no observed adverse effect level (NOAEL), we tested the effects of a large array of oral doses of this toxin for responses on plasma biochemistry, the immune system and hepatic drug metabolism in mice. C57B16 mice received oral doses of toxin $(0.014,0.071,0.355,1.774$ or $8.87 \mathrm{mg} / \mathrm{kg}$ bw) 3 days a week for 4 weeks. Only the highest dose of NIV induced an increase in plasma phosphate, decreases in plasma urea and immunoglobulin $\mathrm{M}$ and additional changes like increases in plasma alkaline phosphatase and immunoglobulin G. Interleukin 4 production was increased in cultured murine splenocytes. Regarding liver drug metabolising enzymes, the only glutathione transferase activity accepting 1-chloro-2,4-dinitro-benzene as substrate was transiently increased in mice receiving low doses ( 0.071 and $0.355 \mathrm{mg} / \mathrm{kg} \mathrm{bw})$ of NIV. Regarding the cytochrome P450 monooxygenases, no significant change was observed in ethoxyresorufin $O$-deethylase activity whereas both methoxyresorufin and pentoxyresorufin $O$-dealkylase activities were decreased by $38-45 \%$ for the highest dose $(8.87 \mathrm{mg} / \mathrm{kg} \mathrm{bw})$ of NIV. However, when analysed by Western blot analysis, the protein expression of mouse P450 1a, 2b, 2c, 3a and $4 \mathrm{a}$ subfamilies was unchanged in animals receiving NIV. In conclusion, the NOAEL of this toxin in our study was $1.774 \mathrm{mg} / \mathrm{kg}$ bw, corresponding to an exposure to $5 \mathrm{ppm}$ contaminated food. Indeed hepatotoxicity appears in the only mice treated with a five fold higher oral dose of $8.87 \mathrm{mg} / \mathrm{kg}$ bw of NIV. Such exposure levels appear to be by far higher than the maximal natural occurrence measured in European cereals, known to range from 0.34 to $1.86 \mathrm{ppm}$.
\end{abstract}

mice / nivalenol / immunotoxicity / biotransformation enzymes

\section{INTRODUCTION}

Trichothecenes are secondary metabolites synthesised by Fusarium and related species of fungi which contaminate cereal grains in many parts of the world. Consumption of trichothecene-contaminated grains is associated with several clinical

\footnotetext{
* Corresponding author:

pgaltier@toulouse.inra.fr
} 
changes in both animals and humans. In this paper, we were interested in nivalenol (NIV), a trichothecene which co-occurs regularly with deoxynivalenol throughout the world. So, in a recent report ${ }^{1}, 16 \%$ of NIV-positive samples have been described in 4166 cereal samples from Europe with contamination levels ranging from limit of detection (2 to $7 \mu \mathrm{g} / \mathrm{kg}$ ) to $340,351,440$ and $1860 \mu \mathrm{g} / \mathrm{kg}$ (or 0.34, 0.351, 0.44 and $1.86 \mathrm{ppm}$ ) for maize, barley, wheat and oats respectively.

Various toxicological studies have been done using high doses of NIV but there is a lack of data regarding the effects of low oral doses of NIV in animal models. When administered in short-term assays, at doses higher than $6 \mathrm{ppm}$ in animal feeds, NIV has been described to cause feed refusal, decrease in weight gain, increase in serum alkaline phosphatase activity and elevation of serum IgA level and mesangial $\operatorname{IgA}$ deposits in mice $[9,22]$. Doses of 2.5 or $5 \mathrm{mg} / \mathrm{kg}$ of pure NIV added to the diet of young pigs, caused pathological alterations in the kidneys and gastrointestinal tract and reduced the number of splenocytes [8]. The results also indicated that exposure to NIV causes a time-dependent increase in IgA production in the $2.5 \mathrm{mg} / \mathrm{kg}$ group. Because of these effects on the immune system, the exposure of trichothecenes could predispose humans and animals to infectious disease [15], especially for sensitive human populations like young children, immuno-depressed people and old people. Furthermore, NIV would alter both serum biochemical parameters and hepatic drugmetabolising activities in the rat [21]. NIV is known to induce a transient increase in liver cytochrome $\mathrm{P} 4502 \mathrm{~B} 1 / 2$, together with

\footnotetext{
${ }^{1}$ SCOOP, Collection of occurrence data of Fusarium toxins in food and assessment of dietary intake by the population of EU member states, Directorate-general health and consumer protection [on line] (2003) http://europa.eu.int/ comm/food/fs/scoop/task3210.pdf.
}

an increase in the cytosolic glutathione S-transferase (GST) activity.

The pivotal study [14] considered for Lowest Observed Adverse Effect Level determination was performed in mice fed highly contaminated diets. In consequence, this investigation was conducted to characterise and compare the effects of a wide range of oral doses of pure NIV on defence systems of mice exposed through a subacute (4 weeks) toxicological assay. In most of the previous toxicological studies, animals received toxin-contaminated diets, without any accurate control of the ingested doses of toxins. Here, mice were orally intoxicated by gavage with pure nivalenol.

Although very few studies describe the effects of chronic exposure of NIV at low doses, several countries have established regulations on trichothecenes where only low limits ( 0.5 to $2 \mathrm{ppm}$ ) of contamination in cereals are tolerated. In order to clearly evaluate a no observed adverse effect level (NOAEL) of this toxin on defence systems, three low doses of toxin administered three times a week for four weeks, were used $(0.014,0.071$ or $0.355 \mathrm{mg} / \mathrm{kg} \mathrm{bw})$. This experimental outline has been selected to reflect a putative natural food contamination. Indeed, these doses correspond to usual contaminations (0.05, 0.2 and $1 \mathrm{ppm})$ occurring naturally in cereals. Two higher doses (1.774 and $8.87 \mathrm{mg} / \mathrm{kg}$ bw corresponding to 5 and $25 \mathrm{ppm}$ ) were also administered as positive controls. These doses have been commonly used in previous NIV toxicological investigations in mice $[14,18,22]$. Moreover, our group has recently published a similar study on the effects of various doses of deoxynivalenol on xenobiotic metabolising enzymes in mice [3]. In the present study, the results were compared in terms of body weights, serum biochemistry and various parameters describing the immune system response and the hepatic drug metabolism capacity. 


\section{MATERIALS AND METHODS}

\subsection{Chemicals}

Pure mycotoxin NIV, NADPH, ethoxyresorufin, methoxyresorufin, resorufin, concanavalin A type IV (ConA), $O$-phenylene-diamine dichlorhydrate (OPD) and 3,3',5,5'tetramethylbenzidine (TMB) were purchased from Sigma-Aldrich Chemical Co. (Saint-Quentin-Fallavier, France). 1-Chloro-2,4-dinitrobenzene (CDNB) and 1,2-dichloro-4-nitrobenzene (DCNB) were obtained from SigmaAldrich. Immunoglobulins and anti-mouse immunoglobulins were obtained from Bethyl Laboratories Inc. (Montgomery, USA). Rabbit anti-rat P4502C7, rabbit anti-mouse P4501a1/1a2, rabbit anti-rat P450 3A1/3A2 were generous gifts from Dr P. Beaune (INSERM UMR775, Paris). Goat anti-rat P4504A1 and goat antirat P4502B1/2B2 were obtained from Daiichi Pure Chemicals (Tokyo, Japan). Recombinant cytokines and rat anti-mouse cytokine antibodies were purchased from Ebioscience (San Diego, USA). All other chemicals and reagents were the highest grade available. Distilled deionised water was used in all studies.

\subsection{Animals}

All experimental procedures with animals were in accordance with the European Guidelines for the Care and Use of Animals for Research Purposes. C57B16 male mice (6 week-old, Iffa Credo, Les Oncins, France) were housed 6 per cage and allowed food and water ad libitum. Animals were acclimatised to housing $\left(22{ }^{\circ} \mathrm{C}\right)$, feed, a 12-h light/dark cycle and a negative pressure ventilated area for 7 days prior to starting experiments. The animals were randomly divided into 6 groups of 10 mice: one control group and five treated groups receiving 0.014 ,
$0.071,0.355,1.774$ or $8.870 \mathrm{mg}$ of NIV per kg of body weight. Crystalline toxin solubilised in 5\% (w/v) arabic gum solution in water $(150 \mu \mathrm{L}$ per animal), was administered orally every two days three times a week for 4 weeks. By considering the daily food consumption of the animals (3.3 g per mouse), these doses corresponded to food contaminations of $0.11,0.47,2.33,11.67$ and $58.35 \mathrm{ppm}$ given for 3 days a week, respectively. They also correspond to daily average intakes of $0.05,0.2,1,5$ and 25 ppm contaminated feed applied for 4 consecutive weeks. Control groups received the vehicle alone. The body weight of each mouse was measured 3 times a week. After 4 weeks, mice were killed by cervical dislocation; this technique was approved by a local ethics committee. Blood samples were collected by cardiac puncture and plasmas separated by centrifugation at $1600 \mathrm{~g}$ for $10 \mathrm{~min}$ and kept at $-20{ }^{\circ} \mathrm{C}$ before analysis. In each group, plasmas from two different animals were randomly pooled. Spleen, liver and kidneys were removed immediately, weighed, washed with ice-cold saline solution and blotted free of excess moisture under sterile conditions. Spleens were used immediately for splenocyte culture preparations and livers were frozen in liquid nitrogen and kept at $-80{ }^{\circ} \mathrm{C}$ until use.

\subsection{Plasma biochemistry and immunoglobulin analyses}

Activity of alkaline phosphatase and concentration of sodium (Na), chlorine (Cl), $\mathrm{CO}_{2}$, phosphate, urea, osmolarity and glucose were measured using an automatic serum analyser (Hitachi 991, Roche, Basel, Switzerland). IgA, IgM and IgG were measured in plasma by ELISA. Microtitre strip wells (Corning Inc., New York, USA) were coated overnight at $4{ }^{\circ} \mathrm{C}$ with $50 \mu \mathrm{L} /$ well of heavy-chain specific goat anti-mouse IgA, $\operatorname{IgM}$ or $\operatorname{IgG}$ at a concentration of $10 \mu \mathrm{g} / \mathrm{mL}$ 
in a $0.05 \mathrm{M}$ bicarbonate buffer ( $\mathrm{pH}$ 9.6). Coated plates were washed three times with TBS buffer ( $\mathrm{pH} 8$ ) containing $0.05 \%$ tween 20 (TBST). Wells were incubated with $200 \mu \mathrm{L}$ of $1 \%$ bovine serum albumin (BSA) in TBS (1 h, RT) to block nonspecific protein binding and then washed three times with TBS. For $\operatorname{IgA}$, IgM and IgG determination, standard mouse reference serum or plasma was diluted in BSA $1 \%$-TBST buffer and $50 \mu \mathrm{L}$ was added to the appropriate well. Plates were incubated for $2 \mathrm{~h}$ and then washed 4 times with TBST and $50 \mu \mathrm{L}$ of goat anti-mouse $\operatorname{IgA}$, IgM or IgG horseradish peroxydase (diluted 1/40000, 1/120000 and 1/90000, respectively) in BSA $1 \%$-TBST was added to each well. Plates were incubated for $1 \mathrm{~h}$ and washed 6 times with TBST. For bound peroxydase determination, $50 \mu \mathrm{L}$ of O-phenylene-diamine dichlorhydrate solution $(40 \mathrm{mg} / 100 \mathrm{~mL} 0.15 \mathrm{M}$ citrate buffer, $\mathrm{pH}$ 5.0) was added to each well. The reaction was stopped by addition of $50 \mu \mathrm{L}$ $3 \mathrm{M}$ sulphuric acid after 5-30 min of incubation and the absorbance of the developed colour was determined spectrophotometrically at $520 \mathrm{~nm}$ on an ELISA reader (Spectra Thermo, Tecan, USA).

\subsection{Splenocyte culture and assays}

Spleens obtained from individual mice were minced and homogenised in Roswell Park Memorial Institute (RPMI) medium. Following lysis of contaminated red blood cells with $0.16 \mathrm{M}$ ammonium chloride, spleen cells were resuspended at a final concentration of $1 \times 10^{6} / \mathrm{mL}$ in RPMI-1640 medium supplemented with $10 \%$ fetal calf serum, $100 \mathrm{U} / \mathrm{mL}$ penicillin, $50 \mu \mathrm{g} / \mathrm{mL}$ streptomycin and glutamine $2 \mathrm{mM}$ (Eurobio, Les Ulis, France). Cells $\left(10^{6}\right)$ were seeded in 24-well tissue culture plates (Starstedt Inc, Newton, USA) in a humidified incubator with a $5 \% \mathrm{CO}_{2}$ atmosphere and stimulated or not with $10 \mu \mathrm{g} / \mathrm{mL}$
ConA. Culture supernatants were collected $72 \mathrm{~h}$ later and stored at $-80{ }^{\circ} \mathrm{C}$ for cytokine analysis. IL-4, IL- 6 and IFN- $\gamma$ were measured by ELISA with specific antibody pairs (Ebioscience). Briefly, purified anti IL-4, IL-6 and IFN- $\gamma$ (clones 11B11, MP520F3 and XMG1.2 respectively) were used as capture antibodies with the corresponding biotinylated anti-murine IL-4, IL-6 and IFN- $\gamma$ monoclonal antibodies (clone BUD6-24G2, MP5-32C11 and R4-6A2 respectively). Horseradish peroxydase avidin $\mathrm{D}$ (Ebioscience) and TMB substrate kit (Perbio Science) were used for detection. Absorbance was read at $450 \mathrm{~nm}$. Dilutions of recombinant murine cytokines were used as standards and the results are expressed as nanograms of cytokine/mL.

\subsection{Liver enzyme preparation and assays}

For each animal, $1 \mathrm{~g}$ of liver was homogenised with $2.5 \mathrm{~mL}$ of ice-cold $0.1 \mathrm{M}$ potassium phosphate buffer $(\mathrm{pH}$ 7.4) in a glass Potter homogeniser with a Teflon pestle. The homogenate was centrifuged at $10000 \mathrm{~g}$ for $30 \mathrm{~min}$. The supernatant was then collected and centrifuged at $105000 \mathrm{~g}$ for $1 \mathrm{~h}$ (Centrikon T1170 centrifuge). The microsomal pellets were resuspended in storage buffer (potassium buffer $\mathrm{KH}_{2} \mathrm{PO}_{4} / \mathrm{K}_{2} \mathrm{HPO}_{4} 0.1 \mathrm{M}+0.1 \mathrm{mM}$ EDTA, $20 \%$ glycerol), aliquoted and then stored at $-80{ }^{\circ} \mathrm{C}$. The microsomal and cytosolic (105 $000 \mathrm{~g}$ supernatant) protein concentrations were determined using a BCA Assay Kit (Pierce, Interchim, Montluçon, France) using bovine serum albumin as the standard. The microsomal cytochrome P450 (P450) depending activities ethoxyresorufin, methoxyresorufin and pentoxyresorufin $O$-dealkylations (EROD, MROD and PROD) were determined spectrofluorometrically [11] while cytosolic glutathione S-transferase (GST) were assayed using either $1 \mathrm{mM}$ 
Table I. Effects of 5 oral doses of nivalenol administered 3 days a week for 4 weeks, on body and liver weights and on protein levels in the liver of C57BL/6 mice. Values are expressed as means \pm SEM and represent the analysis of 6 groups of 10 mice each.

\begin{tabular}{|c|c|c|c|c|c|c|}
\hline \multirow[b]{2}{*}{ Parameter } & \multirow[b]{2}{*}{0 (control) } & \multicolumn{5}{|c|}{ Oral dose of NIV (mg/kg bw) } \\
\hline & & 0.014 & 0.071 & 0.355 & 1.774 & 8.87 \\
\hline $\begin{array}{l}\text { Initial body } \\
\text { weight }^{\mathrm{a}}\end{array}$ & $23.57 \pm 0.21$ & $23.53 \pm 0.20$ & $23.39 \pm 0.22$ & $23.60 \pm 0.35$ & $23.30 \pm 0.28$ & $23.30 \pm 0.18$ \\
\hline $\begin{array}{l}\text { Terminal bod } \\
\text { weight }^{\mathrm{a}}\end{array}$ & $25.15 \pm 0.30$ & $24.57 \pm 0.25$ & $24.40 \pm 0.26$ & $24.58 \pm 0.35$ & $24.24 \pm 0.33 *$ & $23.30 \pm 0.28^{*}$ \\
\hline $\begin{array}{l}\text { Relative liver } \\
\text { weight }^{\text {b }}\end{array}$ & $4.73 \pm 0.25$ & $4.66 \pm 0.08$ & $4.71 \pm 0.10$ & $4.52 \pm 0.06$ & $4.49 \pm 0.10$ & $4.46 \pm 0.14$ \\
\hline $\begin{array}{l}\text { Microsomal } \\
\text { proteins }^{\mathrm{c}}\end{array}$ & $4.25 \pm 0.35$ & $3.32 \pm 0.38$ & $4.21 \pm 0.64$ & $3.50 \pm 0.48$ & $4.67 \pm 0.43$ & $5.20 \pm 0.46$ \\
\hline $\begin{array}{l}\text { Cytosolic } \\
\text { proteins }^{\mathrm{d}}\end{array}$ & $35.88 \pm 1.03$ & $32.10 \pm 1.74$ & $34.66 \pm 3.90$ & $35.53 \pm 3.60$ & $36.15 \pm 3.76$ & $35.93 \pm 2.90$ \\
\hline
\end{tabular}

* Significant differences $(P<0.05)$ with control group (Student's $t$-test).

${ }^{a}$ Initial and terminal body weights in $\mathrm{g}$.

${ }^{\mathrm{b}} \mathrm{g}$ liver per $100 \mathrm{~g}$ body weight.

${ }^{c} \mathrm{mg}$ microsomal protein per $\mathrm{g}$ liver.

${ }^{\mathrm{d}} \mathrm{mg}$ cytosolic protein per $\mathrm{g}$ liver.

CDNB or DCNB [6]. For the determination and quantification of cytochrome P450 isoenzymes, solubilised microsomes (5 pmoles) were electrophoresed in $9 \%$ polyacrylamide gel in the presence of sodium dodecylsulfate [10]. The separated microsomal proteins were transferred to nitrocellulose membranes [20]. Blots were stained using diaminobenzidine or a chemiluminescence technology (ECL kit, Amersham) following incubations with a primary anti-P450 antibody and a secondary peroxidase-labelled antibody. Relative content of each P450 isoform was estimated by densitometry of the Western blots using an Omnimedia XRS 12 CX Bioimage Scanner (Roissy, France). Band intensities were compared between control and treated samples.

\subsection{Statistical analysis}

The results are reported as the mean \pm SEM for 10 animals or 5 pooled samples for the biochemistry analysis of plasma samples. After determination of the homogeneity of variance (Hartley's test), statistical analysis of the data was carried out using one-way (dose effect of NIV) analysis of variance followed by a post hoc test of Fisher's PLSD. All statistics were carried out using Stat View Software (Cary, USA). A probability of $P<0.05$ was considered significant.

\section{RESULTS}

\subsection{Body and organ weights}

Body weights were monitored three times a week throughout the 4 week exposure period. At week 0 , mean body weights of all groups were statistically similar (Tab. I). Exposure to the three low doses of NIV did not induce any change in body weight. However, significant decreases in body weights were observed in animals receiving the two highest doses of 
Table II. Effects of 5 oral doses of nivalenol administered 3 days a week for 4 weeks, on plasma biochemical parameters of C57BL/6 mice. Values are expressed as means $\pm \mathrm{SEM}$ and represent the analysis of 6 groups of 5 pooled plasma from 2 mice each.

\begin{tabular}{lcccccc}
\hline & & \multicolumn{5}{c}{ Oral dose of NIV $(\mathrm{mg} / \mathrm{kg} \mathrm{bw})$} \\
\cline { 3 - 7 } Parameter & 0 (control) & 0.014 & 0.071 & 0.355 & 1.774 & 8.87 \\
\hline $\mathrm{Na}(\mathrm{mmol} / \mathrm{L})$ & $165.2 \pm 0.4$ & $161.3 \pm 2.8$ & $62.5 \pm 2.8$ & $165.5 \pm 1.6$ & $162.2 \pm 2.3$ & $160.2 \pm 1.8$ \\
$\mathrm{Cl}(\mathrm{mmol} / \mathrm{L})$ & $108.0 \pm 0.8$ & $108.70 \pm 0.3$ & $107.7 \pm 0.7$ & $107.8 \pm 0.7$ & $106.4 \pm 0.8$ & $108.4 \pm 0.68$ \\
$\mathrm{TCO}_{2}(\mathrm{mmol} / \mathrm{L})$ & $14.25 \pm 1.11$ & $14.33 \pm 1.86$ & $14.75 \pm 0.85$ & $14.20 \pm 0.73$ & $14.00 \pm 0.55$ & $15.40 \pm 1.43$ \\
$\mathrm{TP}(\mathrm{mmol} / \mathrm{L})$ & $47.7 \pm 2.5$ & $50.7 \pm 2.4$ & $48.0 \pm 3.6$ & $44.4 \pm 1.3$ & $45.2 \pm 1.6$ & $48.8 \pm 1.3$ \\
$\mathrm{Urea}(\mathrm{g} / \mathrm{L})$ & $0.44 \pm 0.02$ & $0.46 \pm 0.03$ & $0.43 \pm 0.01$ & $0.45 \pm 0.01$ & $0.44 \pm 0.01$ & $0.34 \pm 0.02^{*}$ \\
$\mathrm{CREA}(\mathrm{mg} / \mathrm{L})$ & $2.67 \pm 0.06$ & $2.53 \pm 0.67$ & $3.07 \pm 0.21$ & $2.96 \pm 0.18$ & $3.02 \pm 0.17$ & $2.94 \pm 0.18$ \\
$\mathrm{Glucose}(\mathrm{g} / \mathrm{L})$ & $1.92 \pm 0.17$ & $2.10 \pm 0.15$ & $2.00 \pm 0.14$ & $1.92 \pm 0.24$ & $1.74 \pm 0.13$ & $1.44 \pm 0.09^{*}$ \\
$\mathrm{Ca}(\mathrm{mg} / \mathrm{L})$ & $90.7 \pm 4.2$ & $94.3 \pm 3.8$ & $91.0 \pm 6.6$ & $86.2 \pm 2.0$ & $84.4 \pm 4.3$ & $89.0 \pm 3.3$ \\
$\mathrm{P}(\mathrm{mg} / \mathrm{L})$ & $74.2 \pm 8.1$ & $75.3 \pm 7.3$ & $78.7 \pm 11.6$ & $73.6 \pm 7.2$ & $74.0 \pm 4.8$ & $83.2 \pm 4.5$ \\
$\mathrm{ALP}(\mathrm{U} / \mathrm{L})$ & $216.4 \pm 14.1$ & $234.0 \pm 16.7$ & $232.2 \pm 13.3$ & $232.7 \pm 6.7$ & $235.4 \pm 10.5$ & $277.2 \pm 31.7 *$ \\
$\mathrm{UA}(\mathrm{mg} / \mathrm{L})$ & $43.2 \pm 1.4$ & $54.3 \pm 10.7$ & $46.2 \pm 6.4$ & $39.4 \pm 0.9$ & $38.0 \pm 3.1$ & $29.0 \pm 0.71$ \\
$\mathrm{CHOL}(\mathrm{g} / \mathrm{L})$ & $0.89 \pm 0.08$ & $1.05 \pm 0.09$ & $0.85 \pm 0.12$ & $0.88 \pm 0.02$ & $0.79 \pm 0.03$ & $0.71 \pm 0.03^{*}$ \\
$\mathrm{TG}(\mathrm{g} / \mathrm{L})$ & $0.77 \pm 0.05$ & $0.73 \pm 0.01$ & $0.64 \pm 0.04$ & $0.74 \pm 0.04$ & $0.65 \pm 0.06$ & $0.48 \pm 0.02^{*}$ \\
\hline
\end{tabular}

* Significant differences $(P<0.05)$ with control group (Student's $t$-test).

$\mathrm{TCO}_{2}=$ total $\mathrm{CO}_{2} ; \mathrm{TP}=$ total proteins; CREA = creatinin; $\mathrm{P}=$ phosphate; $\mathrm{ALP}=$ alkaline phosphatase; $\mathrm{UA}=$ uric acid $; \mathrm{CHOL}=$ cholesterol $; \mathrm{TG}=$ triglycerides .

NIV (1.77 and $8.87 \mathrm{mg} / \mathrm{kg})$ when compared to control mice. There was no effect of any 4-week long NIV treatment on the weights of mouse spleen, kidneys (data not shown) or liver (Tab. I). Regarding the liver, no statistical difference between the treated and control groups was observed in both hepatic microsomal and cytosolic protein contents (Tab. I).

\subsection{Plasma biochemistry}

Biochemical profiles were determined on pooled plasmas. As indicated in Table II, all measured parameters were unaffected by the lowest doses of NIV (0.014 to $1.774 \mathrm{mg} / \mathrm{kg}$ ). However, in mice treated with $8.87 \mathrm{mg} / \mathrm{kg}$ of NIV, plasma levels of alkaline phosphatase were significantly increased (28\%) whereas urea, glucose, cholesterol and triglyceride levels in plasma were significantly decreased (20 to $38 \%$ ) when compared to controls.

\subsection{Plasma immunoglobulins}

After sacrifice of animals at week 4, blood was collected by intracardiac puncture and serum $\operatorname{IgA}, \operatorname{IgM}$, and $\operatorname{IgG}$ were individually analysed to determine whether the various doses of NIV had an effect on the isotype distribution of these proteins. As shown in Figure 1, no significant change was observed in both IgA and $\operatorname{IgM}$ levels following administration of NIV. The only effect observed on plasma immunoglobulins, consisted in a 50\% increase in IgG level in animals receiving the highest dose of NIV $(8.87 \mathrm{mg} / \mathrm{kg})$.

\subsection{Cytokine release by splenocytes}

The effect of the four week oral administration of NIV on cytokine production was investigated. The release of IL-4, IL-6 and IFN- $\gamma$ was measured in splenocytes isolated from control or treated mice and 

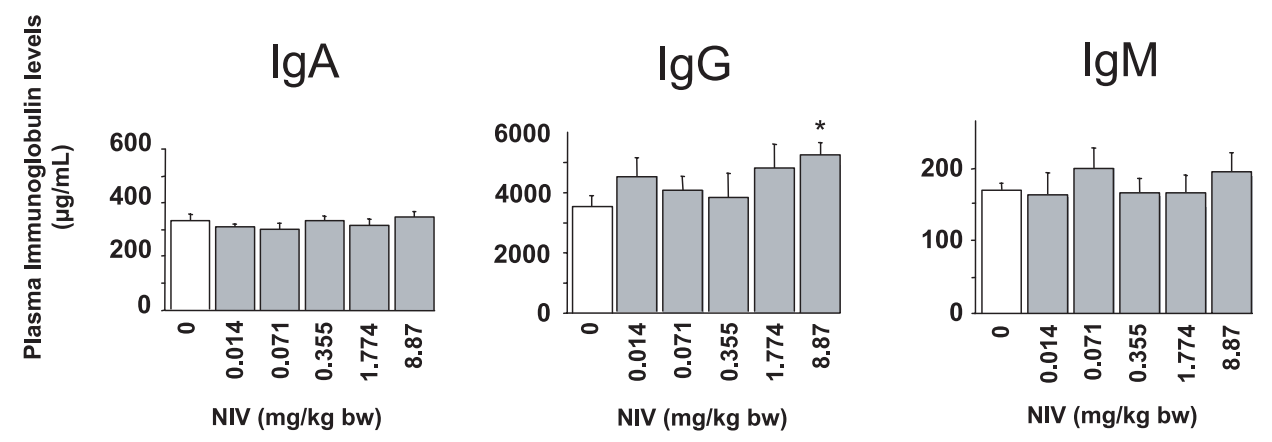

Figure 1. Effects of 5 oral doses of nivalenol administered 3 days a week for 4 weeks, on plasma immunoglobulin levels in male mice. Each bar represents the mean \pm SEM for ten individual mice. Asterisk indicates significant difference with controls receiving the vehicle alone $(P<0.05)$.
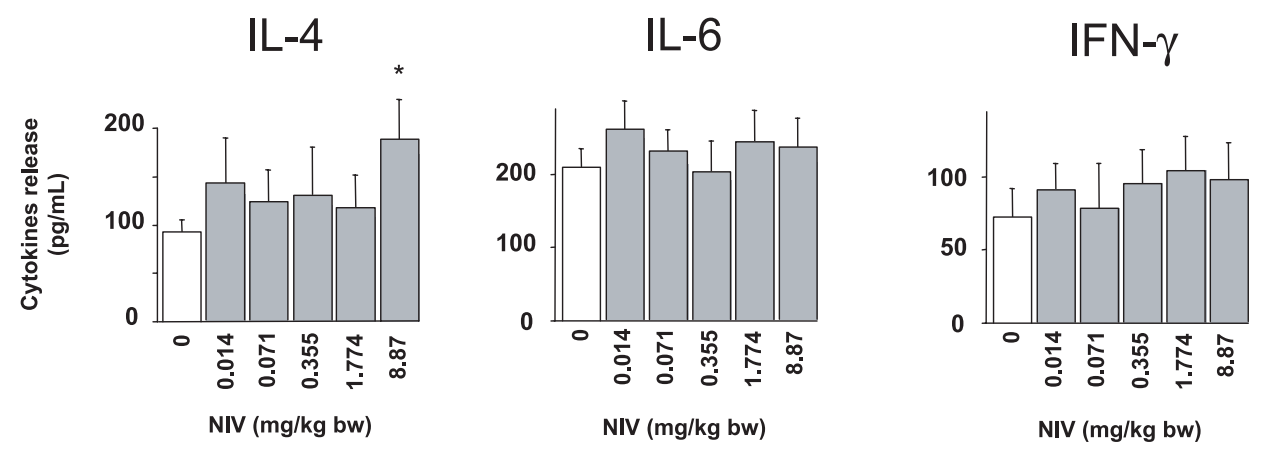

Figure 2. Effects of 5 oral doses of nivalenol administered 3 days a week for 4 weeks, on IL-4, IL-6 and IFN- $\gamma$ released in cultured splenocytes from male mice upon ConA stimulation. Each bar represents the mean \pm SEM for spleens from ten mice. Asterisk indicates significant difference with controls receiving the vehicle alone $(P<0.05)$.

cultured for $72 \mathrm{~h}$, in the presence or absence of ConA mitogen.

In NIV-treated animals (Fig. 2), no effect was observed on the production of IL- 6 or IFN- $\gamma$ by cultured splenocytes compared to controls (210 and 67 $\mathrm{ng} / \mathrm{mL}$, respectively). Splenocytes from animals receiving the highest dose of NIV $(8.87 \mathrm{mg} / \mathrm{kg})$ produced significantly higher concentrations of IL-4 after $72 \mathrm{~h}$ of culture. Other treatment doses had no significant effect on IL-4 production compared to controls. Non stimulated splenocytes did not produce any detectable cytokine secretion (data not shown).

\subsection{Liver biotransformation enzymes}

Patterns of P450 expression and P450 or GST activities were explored to study specific effects of NIV on mouse hepatic biotransformation enzymes after 4 weeks of exposure. As shown in Figure 3, in mice treated with NIV, no significant change was observed in ethoxyresorufin $O$ deethylase (EROD) activities for all investigated doses whereas methoxyresorufin $O$-demethylase (MROD) and pentoxyresorufin $O$-depentylase (PROD) activities were respectively decreased by 38 and $45 \%$ for the highest dose $(8.87 \mathrm{mg} / \mathrm{kg})$. By 

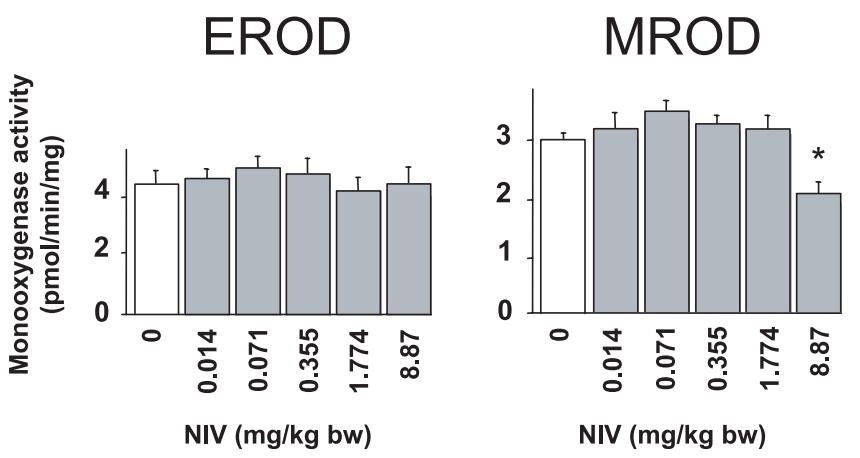

PROD

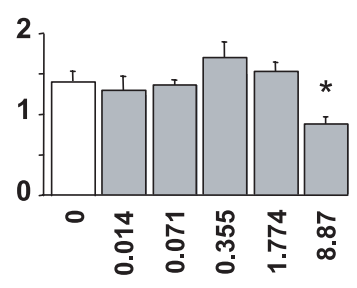

NIV (mg/kg bw)

Figure 3. Effects of 5 oral doses of nivalenol administered 3 days a week for 4 weeks, on liver monooxygenase activities (EROD: ethoxyresorufin $O$-deethylation, MROD: methoxyresorufin $O$-demethylation, PROD: pentoxyresorufin $O$-depentylation). Each bar represents the mean \pm SEM for ten mice. Asterisks indicate significant differences with controls receiving the vehicle alone $(P<0.05)$.

contrast, when explored by Western blot analysis, the protein expression of mouse P450 1a, 2b, 2c, 3a and 4a subfamilies was unchanged in animals receiving NIV, independently of the dose (Fig. 4). This was confirmed by densitometry analysis realised on blots from 4 animals in each group of treatment (data not shown).

Liver cytosolic GST activities were measured with either CDNB or DCNB as substrate $(1.82 \mu \mathrm{mol} / \mathrm{min} / \mathrm{mg}$ and $3.06 \mathrm{nmol} / \mathrm{min} / \mathrm{mg}$ in controls, respectively), as shown in Figure 5. Doses of 0.071 and $0.355 \mathrm{mg} / \mathrm{kg}$ of NIV provoked significant increases (34 and 24\%, respectively) of hepatic GST accepting CDNB as substrate whereas no change in GST activity accepting DCNB as substrate was observed in mice for all treatment doses of NIV.

\section{DISCUSSION}

In the present study, administration of the two highest doses of pure NIV (1.77 and $8.87 \mathrm{mg} / \mathrm{kg}$ three times a week) decreased the terminal body weight of mice exposed to a 4 week short-term assay. Such decrease in body weight was observed in mice fed for 4 weeks with 6 to $30 \mathrm{ppm}$ NIV contaminated diets $[18,22]$. These results are in agreement with our observations carried on animals exposed to the highest doses administrated, corresponding to daily average intakes of 5 and $25 \mathrm{ppm}$ contaminated feed applied for four consecutive weeks.

Concerning the plasma biochemistry, significant biochemical changes were only observed in mice receiving the highest dose of nivalenol $(8.87 \mathrm{mg} / \mathrm{kg}$ three times a week, for four weeks). Certain parameters like sodium or chlorine appeared to be insensitive to nivalenol as previously demonstrated in the chicken [7]. Alkaline phosphatase activity was increased whereas plasma urea, glucose, triglycerides and cholesterol levels were decreased in the group of mice receiving the highest dose of NIV. With the exception of urea, similar observations have been previously reported in mice exposed for 4 weeks to diets contaminated by 6 to $30 \mathrm{ppm}$ of NIV [22] or in laying hens receiving pure NIV in the diet [3]. The simultaneous changes in plasma urea levels and alkaline phosphatase activity reflect a hepatotoxicity in mice receiving the highest dose of NIV. 


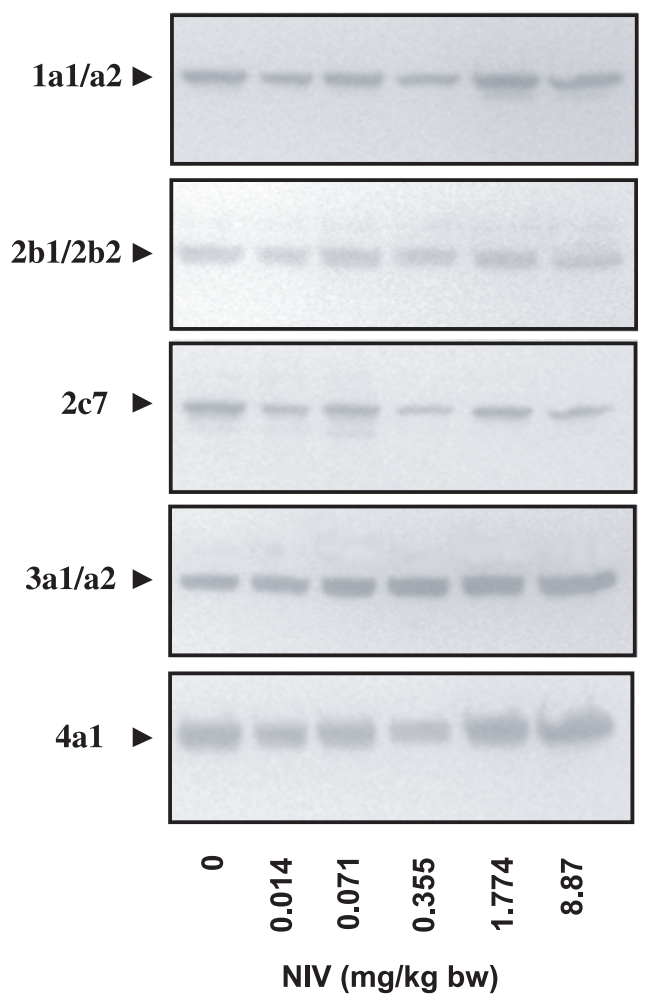

Figure 4. Western blot analysis of cytochrome P450 subfamily expression in liver microsomes of mice exposed to nivalenol for 4 weeks*. Microsomal protein samples $(n=4$ for each group of treatment) were submitted to electrophoresis, transferred to nitrocellulose membranes and probed with polyclonal antibodies prepared against mouse liver cytochrome P450 1a1/a2 or rat liver cytochrome P450 2C7, 2B1/2, 3A1/2 and 4A1. * Shown are fluorograms of Western blot membranes representatives of 4 distinct analysis data realised on different individual mice hepatic microsomes.
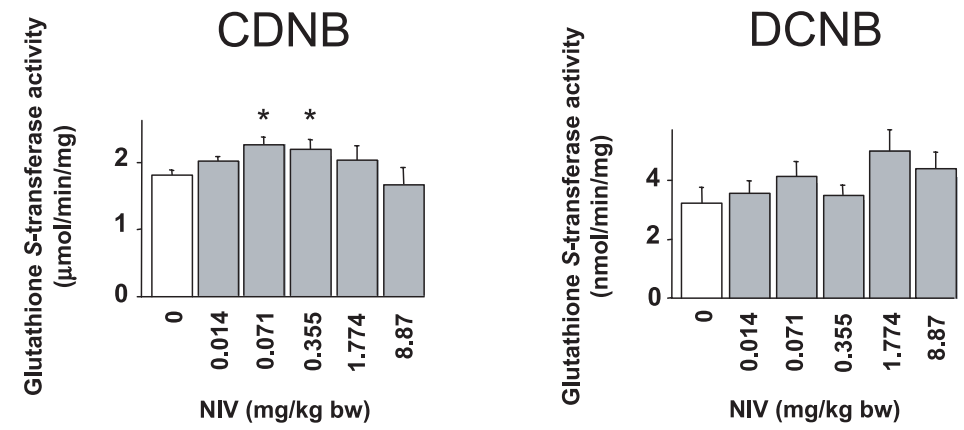

Figure 5. Effects of 5 oral doses of nivalenol administered 3 days a week for 4 weeks, on liver glutathione S-transferase activities (CDNB: 1-chloro-2,4-dinitrobenzene, DCNB: 1,2-dichloro-4nitrobenzene as substrates). Each bar represents the mean \pm SEM for ten mice. Asterisks indicate significant differences with controls receiving the vehicle alone $(P<0.05)$. 
Due to the well-established isotypespecific dysregulation of immunoglobulin production in pigs exposed to NIV [8], the effects of various doses of this toxin were compared on plasma immunoglobulin profiles of mice. NIV treatments did not alter the plasma levels of both $\operatorname{IgA}$ and IgM, independently of the dose. By contrast, plasma IgG levels were increased in mice receiving the highest dose of NIV $(8.87 \mathrm{mg} / \mathrm{kg}$ three times a week, for 4 weeks). This result was consistent with previous data demonstrating unchanged $\operatorname{IgM}$ and increased $\mathrm{IgG}$ in mice fed with 12 ppm NIV for 8 weeks [9]. However, this study reported that NIV ingestion like deoxynivalenol induced significant $\operatorname{IgA}$ deposits in the glomerular mesangium and elevated serum IgA levels in mice. The degree of immunopathological changes was associated with the dose and duration of NIV treatment. The difference between both studies could be explained by the short NIV exposure in our study which may be insufficient to induce dysregulation of IgA production and associated nephropathy symptoms. Another reason explaining this difference could be the different sensitivity of mice strains to trichothecenes [5].

There are only few reports investigating the impact of repeated NIV exposure on cytokine secretion by spleen cells. Our data demonstrated a significant increase in IL-4 level in spleen cell cultures from mice exposed chronically to $8.87 \mathrm{mg} / \mathrm{kg}$ bw whereas no changes were found on IL- 6 and IFN- $\gamma$ levels. This result was consistent with a previous study [1] describing a 4-fold increase in IL-4 and no change in IFN- $\gamma$ levels in stimulated splenocytes prepared from mice fed for 4 weeks with a 6 ppm of NIV contaminated diet. Although NIV has been reported to stimulate Th2 cells to produce cytokines, an increase of IL-4 in primary CD4+ T cells exposed for 7 days to $100 \mathrm{ng} / \mathrm{mL}$ of NIV have been described $[16,17]$. An increase in plasma
IgG levels in mice exposed to $8.87 \mathrm{mg} / \mathrm{kg}$ bw could be related to the increase in IL-4. Indeed, this cytokine is known to induce proliferating and secreting $\mathrm{IgG}$ mouse $\mathrm{B}$ lymphocytes [19].

In our study, the only changes in the activity of liver drug monooxygenases were observed in mice receiving the highest dose of nivalenol $(8.87 \mathrm{mg} / \mathrm{kg}$ of toxin, 3 times a week, for 4 weeks). Decreases in both methoxyresorufin and pentoxyresorufin dealkylations would be different from significant increases in total P450 and $\mathrm{P} 4502 \mathrm{~B} 1 / 2$ isoenzymes described in rats fed 6-12 ppm NIV [22]. Our findings may be explained by the hepatotoxicity revealed at high doses in mice, as demonstrated by the above-mentioned changes in plasma urea levels and alkaline phosphatase activity. Moreover, in a previous investigation [2], we demonstrated decreases in liver P450 monooxygenases in rats receiving oral administrations of the structurally related trichothecens T-2 toxin or diacetoxyscirpenol for 4 or 8 days.

Regarding glutathione S-transferases, CDNB conjugation was increased in mice receiving mid doses of DON or NIV. These findings were in agreement with previous reports describing similar elevations of CDNB conjugation in rats fed these toxins for several weeks $[13,21]$. Similar increases were observed in mice receiving the same mid oral doses of the related trichothecene deoxynivalenol [4]. Although the reason for such increases remains to be explained, we believe that the 12,13-epoxide group characterising these epoxy-trichothecene toxins can be used as a substrate by these conjugating enzymes. This would have consequences on the activity or expression of these proteins, particularly of class mu which have been previously described to be highly active with epoxides [12]. For the highest doses, the return to normal values of these activities could be explained by the hepatotoxicity of these toxins with consequences 
on either liver protein synthesis or limited availability of endogenous glutathione.

To summarise this toxicological evaluation, unique deleterious effects were observed in animals receiving the highest dose of nivalenol $(8.87 \mathrm{mg} / \mathrm{kg}$ three times a week, for four weeks) corresponding to a feed contamination of $25 \mathrm{ppm}$. At high doses, this toxin appears hepatotoxic whereas no adverse effects occurred in mice exposed to lower contaminations. In conclusion, from these data, the NOAEL measured on defence systems in mice of NIV was determined as $1.774 \mathrm{mg} / \mathrm{kg}$ bw corresponding to an exposure to a $5 \mathrm{ppm}$ contaminated food. Such a contamination level is by far higher than the maximal natural occurrence measured in European cereals, ranging from 0.34 to $1.86 \mathrm{ppm}$.

\section{ACKNOWLEDGEMENTS}

This research was supported by a grant from the French Ministry of Research (projet AQS 99SA28). M.E. Gouze was supported by a fellowship from INRA (Institut National de la Recherche Agronomique) and IRTAC (Institut de Recherche Technologique Agroalimentaire des Céréales). We are grateful to D. Marin, I. Taranu, F. Accensi, and S. Bouhet who participated in the animal experiments.

\section{REFERENCES}

[1] Choi C.Y., Nakajima-Adachi H., Kaminogawa S., Sugita-Konishi Y., Nivalenol inhibits total and antigen-specific IgE production in mice, Toxicol. Appl. Pharmacol. (2000) 165:94-98.

[2] Galtier P., Paulin F., Eeckhoutte C., Larrieu G., Comparative effects of T-2 toxin and diacetoxyscirpenol on drug metabolizing enzymes in rat tissues, Food Chem. Toxicol. (1989) 27:215-220.

[3] Garaleviciene D., Pettersson H., Elwinger K., Effects on health and blood plasma parameters of laying hens by pure nivalenol in the diet, J. Anim. Physiol. Anim. Nutr. (2002) 86:389-398.
[4] Gouze M.E., Laffitte J., Rouimi P., Loiseau N., Oswald I.P., Galtier P., Effect of various doses of deoxynivalenol on liver xenobiotic metabolizing enzymes in mice, Food Chem. Toxicol. (2006) 44:476-483.

[5] Greene D.M., Bondy G.S., Azcona-Olivera J.I., Pestka J.J., Role of gender and strain in vomitoxin-induced dysregulation of $\operatorname{IgA}$ production and $\operatorname{IgA}$ nephropathy in the mouse, J. Toxicol. Environ. Health (1994) 43:37-50.

[6] Habig W.H., Pabst M.J., Jakoby W.B., Glutathione S-transferases. The first enzymatic step in mercapturic acid formation, J. Biol. Chem. (1974) 249:7130-7139.

[7] Hedman R., Pettersson H., Engstrom B., Elwinger K., Fossum O., Effects of feeding nivalenol-contaminated diets to male broiler chickens, Poult. Sci. (1995) 74:620-625.

[8] Hedman R., Thuvander A., Gadhasson I., Reverter M., Pettersson H., Influence of dietary nivalenol exposure on gross pathology and selected immunological parameters in young pigs, Nat. Toxins (1997) 5:238-246.

[9] Hinoshita F., Suzuki Y., Yokoyama K., Hara S., Yamada A., Ogura Y., Hashimoto H., Tomura S., Marumo F., Ueno Y., Experimental IgA nephropathy induced by a low-dose environmental mycotoxin, nivalenol, Nephron (1997) 75:469-478.

[10] Laemmli U.K., Cleavage of structural proteins during the assembly of the head of bacteriophage T4, Nature (1970) 227:680685.

[11] Lake B.G., Preparation and characterization of microsomal fractions for studies on xenobiotic metabolism, in: Snell K., Mullock B. (Eds.), Biochemical Toxicology, IRL Press, Oxford, UK, 1987, pp. 183-215

[12] Mannervik B., Danielson U.H., Glutathione transferases, structure and catalytic activity, Crit. Rev. Biochem. (1988) 23:283-337.

[13] Morrissey R.E., Norred W.P., Vesonder R.F., Subchronic toxicity of vomitoxin in Sprague-Dawley rats, Food Chem. Toxicol. (1985) 23:995-999.

[14] Ohtsubo K., Ryu J.C., Nakamura K., Izumiyama N., Tanaka T., Yamamura H., Kobayashi T., Ueno Y., Chronic toxicity of nivalenol in female mice: a 2-year feeding study with Fusarium nivale Fn 2B-moulded rice, Food Chem. Toxicol. (1989) 27:591598. 
[15] Oswald I.P., Marin D.E., Bouhet S., Pinton P., Taranu I., Accensi F., Immuno toxicological risk of mycotoxin for domestic animals in Europe, Food Addit. Contam. (2005) 22:354-360.

[16] Ouyang Y.L., Azcona-Olivera J.I., Pestka J.J., Effects of trichothecene structure on cytokine secretion and gene expression in murine CD4+ T-cells, Toxicology (1995) 104:187-202.

[17] Pestka J.J., Bondy G.S., Alteration of immune function following dietary mycotoxin exposure, Can. J. Physiol. Pharmacol. (1989) 68:1009-1016.

[18] Ryu J.C., Ohtsubo K., Izumiyama N., Nakamura K., Tanaka T., Yamamura H., Ueno Y., The acute and chronic toxicities of nivalenol in mice, Fundam. Appl. Toxicol. (1988) 11:38-47.
[19] Thomson A.W., The Cytokine Handbook, 2nd ed., Academic Press, San Diego, 1994, pp. 99-119.

[20] Towbin H., Staehelin T., Gordon J., Electrophoretic transfer of proteins from polyacrylamide gels to nitrocellulose sheets: procedure and some applications, Proc. Natl. Acad. Sci. USA (1979) 76:4350-4354.

[21] Yabe T., Hashimoto H., Sekijima M., Degawa M., Hashimoto Y., Tashiro F., Ueno Y., Effects of nivalenol on hepatic drugmetabolizing activity in rats, Food Chem. Toxicol. (1993) 31:573-581.

[22] Yamamura H., Kobayashi T., Ryu J.C., Ueno Y., Nakamura K., Izumiyama N., Ohtsubo K., Subchronic feeding studies with nivalenol in C57BL/6 mice, Food Chem. Toxicol. (1989) 27:585-590. 